\title{
Utility Advanced Turbine Systems Program (ATS) Technical Readiness Testing and Pre-Commercial Demonstration
}

\author{
Quarterly Report \\ January 1 - March 31, 1997
}

By:

John Brushwood
RECEIVEL

SEP $>61007$

OSTI

Work Performed Under Contract No.: DE-FC21-95MC32267

For

U.S. Department of Energy

Office of Fossil Energy

Federal Energy Technology Center

Morgantown Site

P.O. Box 880

Morgantown, West Virginia 26507-0880

DATRRUTHON OF THIS DOCUMENT IS UNLAITED

By
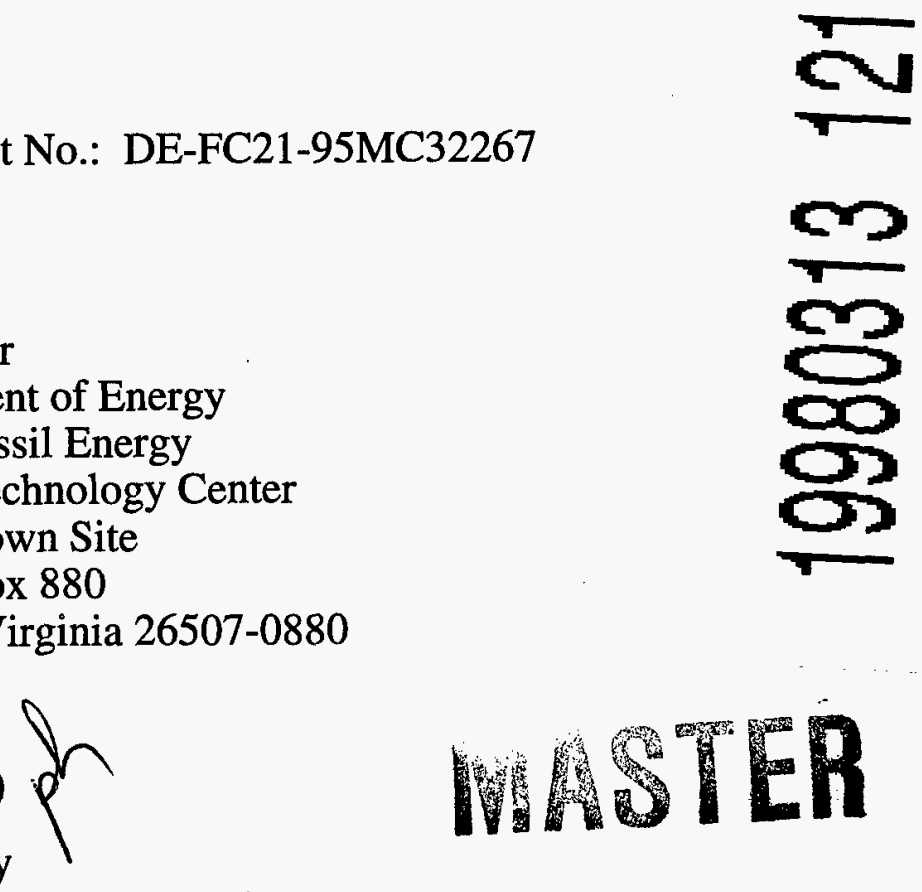

Westinghouse Electric Corporation

Emerging Technologies

4400 Alafaya Trail MC381

Orlando, Florida 32826-2399 


\section{Disclaimer}

This report was prepared as an account of work sponsored by an agency of the United States Government. Neither the United States Government nor any agency thereof, nor any of their employees, makes any warranty, express or implied, or assumes any legal liability or responsibility for the accuracy, completeness, or usefulness of any information, apparatus, product, or process disclosed, or represents that its use would not infringe privately owned rights. Reference herein to any specific commercial product, process, or service by trade name, trademark, manufacturer, or otherwise does not necessarily constitute or imply its endorsement, recommendation, or favoring by the United States Government or any agency thereof. The views and opinions of authors expressed herein do not necessarily state or reflect those of the United States Government or any agency thereof. 


\section{ABSTRACT}

The objective of the ATS program is to develop ultra-high efficiency, environmentally-superior and cost competitive gas turbine systems for base load application in utility, independent power producer and industrial markets. Specific performance targets have been set using natural gas as the primary fuel:

- System efficiency that will exceed $60 \%$ (lower heating value basis) on natural gas for large scale utility turbine systems; for industrial applications, systems that will result in a $15 \%$ improvement in heat rate compared to currently available gas turbine systems.

- An environmentally superior system that will not require the use of post combustion emissions controls under full load operating conditions.

- Busbar energy costs that are $10 \%$ less than current state-of-the-art turbine systems, while meeting the same environmental requirements.

- Fuel-flexible designs that will operate on natural gas but are capable of being adapted to operate on coal-derived or biomass fuels.

- Reliability-Availability-Maintainability (RAM) that is equivalent to the current turbine systems.

- Water consumption minimized to levels consistent with cost and efficiency goals.

- Commercial systems that will enter the market in the year 2000.

In Phase I of the ATS program, Westinghouse found that efficiency significantly increases when the traditional combined-cycle power plant is reconfigured with closed-loop steam cooling of the hot gas path. Phase II activities involved the development of a $318 \mathrm{MW}$ natural gas fired turbine conceptual design with the flexibility to burn coal-derived and biomass fuels. Phases I and II of the ATS program have been completed. Phase III, the current phase, completes the research and development activities and develops hardware specifications from the Phase II conceptual design. Future Phase IV activities consist of manufacturing, constructing, and testing a full-scale natural gas fired ATS plant by the year 2000.

This report summarizes Phase III activities for the preceding three month period. Additional details may be found in monthly technical progress reports covering the period of this report. Background information regarding the work to be completed in Phase III may be found in the Task 8 Program Plan, issued in August 1996. 


\section{TABLE OF CONTENTS}

Section .

EXECUTIVE SUMMARY ..................................................................... 1

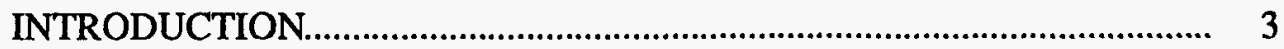

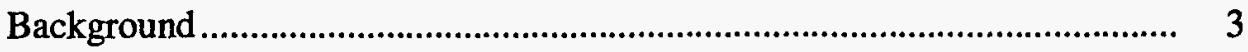

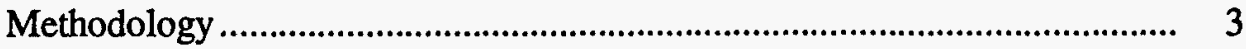

RESULTS AND DISCUSSION ........................................................... 5

Task 1.0 NEPA Information ................................................................... 5

Task 2.0 ATS Engine Design................................................................. 5

Task 3.1 Auxiliary Systems ................................................................. 5

Task 4.1 Steam Turbine ........................................................................... 6

Task 8.0 Integrated Program Plan....................................................... 6

Task 9.1 Closed Loop Cooling ..................................................................... 6

Task 9.2 Thin Wall Casting Development....................................................... 6

Task 9.3 Rotor Air Sealing Development.................................................... 6

Task 9.4 Compressor Aerodynamic Development ......................................... 7

Task 9.5 Turbine Aerodynamic Development ............................................. 7

Task 9.6 Advanced Air Sealing Development............................................. 8

Task 9.7 Active Tip Clearance Control ...................................................... 8

Task 9.8 Combustion System Development.............................................. 8

Task 9.9 Ceramic Ring Segment................................................................. 9

Task 9.10 Advanced Thermal Barrier Coating Development........................ 9

Task 9.11 Steam Cooling Effects....................................................................... 9

Task 9.12 Directionally Solidified Blade Development ................................ 9

Task 9.13 Single Crystal Blade Development .............................................. 10

Task 9.14 Advance Alloy Vane Development........................................... 10

Task 9.15 Blade and Vane Life Prediction ............................................... 10

Task 9.16 Nickel Based Alloy Rotor ........................................................ 10

Task 9.17 Transition Mouth Sealing and Cooling Development.................. 11

Task 9.18 Rotor Cooling Air Compression/Diffuser Development ............... 11

Task 11.0 Program Management ........................................................ 11

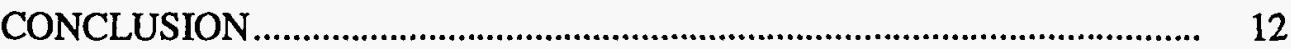

LIST OF ACRONYMS AND ABBREVIATIONS...................................... 15 


\section{EXECUTIVE SUMMARY}

The objective of the ATS program is to develop ultra-high efficiency, environmentally-superior and cost competitive gas turbine systems for base load application in utility, independent power producer and industrial markets. In Phase I of the ATS program, Westinghouse found that efficiency significantly increases when the traditional combined-cycle power plants is reconfigured with closed-loop steam cooling of the hot gas path. Phase II activities involved the development of a 318MW natural gas fired turbine conceptual design with the flexibility to burn coal-derived and biomass fuels. Phases I and II of the ATS program have been completed. Phase III, the current phase, completes the research and development activities and develops hardware specifications from the Phase II conceptual design. Future Phase IV activities consists of manufacturing, constructing and testing a full-scale natural gas fired ATS plant by the year 2000 . This report summarizes Phase III activities for the preceding three month period.

Multi-disciplined teams have been created to address the areas of steam cooling, air cooling, lube oil, enclosures and foundations, static start, piping/pipe rack, inlet system, power electric and the electrical package. A Primavera schedule to coordinate these activities has been developed.

The steam turbine program has proceeded with minor changes in steam flow to accommodate fuel gas heating. Blade path work continues to support the revised target. Coordination meetings with manufacturing have been held for soliciting methods to reduce manufacturing and lead times.

Closed loop cooling activities have proceeded with the test rig in shakedown mode. Purchase orders for manufacture of the test pressure vessel and sealing assemblies were released. Stress analysis of the updated piping layout with size, number, and location of cooling steam piping has been determined.

Casting of the first set of thin wall vanes was completed. Evaluation of casting results is in progress.

A purchase order to John Crane Co. was released for manufacture of the rear face seal.

An intermediate design review was held for the compressor test facility at NAVSSES. A purchase order for the compressor bleed coolers was released. The inlet ducting final design was released. Instrumentation pockets and wireways have been machined into the stage one blades and vanes. Final preparation and cleaning of the airfoils is in progress prior to their shipment to the test facility. Construction of the compressor test building shell was completed. Vane 2 airfoils have been manufactured and shipped to OSU for testing. Full scale compressor diaphragm brush seal manufacture has continued with a trial seal segment successfully welded.

Sermatech International was issued a purchase order to evaluate the abradability and erosion characteristics of two types of compressor abradable coatings. Test samples have been coated and rig testing of the samples is in progress.

Atmospheric fired testing on a piloted ring combustor was successfully completed with encouraging results. Low single digit NOx, as well as single digit $\mathrm{CO}$ and $\mathrm{UHC}$ together with low pressure fluctuations were observed in the tests.

The testing of steam contamination in the blade cooling passages has proceeded. The first test run was recently completed with plugging of all but one of the twelve test specimens. Destructive analysis of the 
scale buildup indicates excess silica, calcium and magnesium were present. Hot corrosion inside the passages was observed.

Single crystal CMSX-4 thick wall test coupons have been shipped to two testing vendors for final machining and testing. Isothermal oxidation test pins of the same material were tested. Results from this test are being evaluated.

A purchase order to EG\&G Sealol was released for the manufacture of a prototype welded bellows transition mouth seal. Bellow seals are set for delivery in July 1997 for installation into the combustor test rig.

Activities on all tasks proceed according to plan, with minor delays in seal development, steam cooling effects tasks and single crystal blade development. The required Federal Assistance Reports were written and submitted on time. A quarterly review meeting was held on February 13 \& 14, 1996 in Morgantown. 


\section{INTRODUCTION}

\section{BACKGROUND}

The National Energy Strategy (NES) calls for a balanced program of greater energy efficiency, use of alternative fuels, and the environmentally responsible development of all U.S. energy resources. Consistent with the NES, a U.S. Department of Energy (DOE) program has been created to develop Advanced Turbine Systems (ATS). The Westinghouse ATS Program is funded and directed by DOE's Morgantown Energy Technology Center (METC). The technical ATS requirements are based upon two workshops held in Greenville, SC that were sponsored by DOE and hosted by Clemson University. The objective of this 8-year program, managed jointly by DOE's Office of Fossil Energy, and, Office of Conservation and Renewable Energy, is to develop natural-gas-fired base load power plants that will have cycle efficiencies greater than $60 \%$, lower heating value (LHV), be environmentally superior to current technology, and also be cost competitive. The program will include work to transfer advanced technology to the coal-and biomass-fueled systems being developed in other DOE programs.

\section{METHODOLOGY}

The Advanced Turbine Systems program is structured into four elements:

- Innovative Cycle Studies

- Utility Advanced Turbine Systems

- Industrial Advanced Turbine Systems

- Technology Base

Within each program element there are several planned phases. For example, the Innovative Cycle Studies element includes two phases.

- Program Definition/Planning Studies

- Concept Development

The objective of the ATS Program is to develop ultra-high efficiency, environmentally-superior, and cost-competitive gas turbine systems for base-load application in utility, independent power producer, and industrial markets. Specific performance targets have been set using natural gas as the primary fuel: 
- System efficiency that will exceed $60 \%$ [lower heating value basis (LHV)] on natural gas for large-scale utility turbine systems; for industrial applications, systems that will result in a $15 \%$ improvement in heat rate compared to currently available gas turbine systems.

- An environmentally superior system that will not require use of post-combustion emissions controls under full-load operating conditions.

- Busbar energy costs that are $10 \%$ less than current state-of-the-art turbine systems, while meeting the same environmental requirements.

- Fuel-flexible designs that will operate on natural gas but are also capable of being adapted to operate on coal-derived or biomass fuels.

- Reliability-Availability-Maintainability (RAM) that is equivalent to the current turbine systems.

- Water consumption minimized to levels consistent with cost and efficiency goals.

- Commercial systems that will enter the market in the year 2000 .

In Phase I of the ATS program, Westinghouse found that efficiency significantly increases when the traditional combined-cycle power plants is reconfigured with closed-loop steam cooling of the hot gas path. Phase II activities involved the development of a 318MW natural gas fired turbine conceptual design with the flexibility to bum coal-derived and biomass fuels. Phases I and II of the ATS program have been completed. Phase III, the current phase, completes the research and development activities and develops hardware specifications from the Phase II conceptual design. Future Phase IV activities consists of manufacturing, constructing and testing a full-scale natural gas fired ATS plant by the year 2000 .

This report summarizes Phase III activities for a three month period. Additional details may be found in monthly technical progress reports covering the period stated on the cover of this report. Background information regarding the work to be completed in Phase III may be found in the Task 8 Program Plan, issued in August 1996. 


\section{RESULTS AND DISCUSSION}

Activities supporting the program tasks are explained below. The task numbers correspond to the task number and task descriptions given in the program plan issued in August 1996.

\section{TASK 1.0 NEPA INFORMATION}

No activity to report in this quarter.

\section{TASK 2.0 ATS ENGINE DESIGN}

The design of the test compressor was completed in July 1996.

Further FEA is being done with Patran, on steam pipes, to verify stresses. Drafting is creating a 3-D, parametric model of the blade ring and associated steam cooling parts.

Stress analysis of updated piping scheme is continuing as surrounding attachment points are moved to accommodate other design considerations. Piping scheme is being adjusted to allow roll in/out so as not to interfere with the key support area. Initial design of 14th stage air supply to row $\# 2$ area has been completed and stress analysis is being performed. Assembly of the flex-slide joints between internal piping and external flanges will be done from outside the CCT. Size, number, and location of steam inlet / exhaust pipes have been determined. Flexible joint durability / leakage test is scheduled to begin in April.

A 14th stage compressor-air manifold has successfully been designed - development will continue. Operating conditions (press, temp, displacements) will dictate the flexible connections necessary for delivery of 14th stage air to the row \#2 vane.

\section{TASK 3.1 AUXILIARY SYSTEMS}

Multi-discipline, multi-division teams have been created to address the areas of Steam Cooling, Air Cooling, Lube Oil, Enclosures and Foundations, Static Start, Piping / Pipe Rack, Inlet System, Power Electric, \& Electrical Package. These teams are responsible for the development of detailed schedules for the completion of tradeoff studies, system optimization studies, etc. meeting aggressive cost targets consistent with overall program goals. Deliverables include design basis documentation, P\&IDs, single line diagrams, equipment specifications and appropriate interface with vendors. These teams have been challenged to collect and monitor the quality of interface data being produced by the equipment designers - CT, Gen, ST. A Lotus notes database is being developed to organize and make available design data. Data quality is a defined field so that auxiliary system / equipment design decisions are made with full knowledge of design quality.

The general approach is to combine ST and CT auxiliary systems to the extent possible and to challenge all standard practices looking for "clean sheet" design options to be evaluated against current practice. As new systems are developed the teams will also conduct design reviews. To support the above activities which feed the detailed design of a number of less "mission critical" and costly systems, a detailed Primavera schedule has been developed and is in the final stages of task integration. 
Over the next period we anticipate several significant events. Cycle design and the power block arrangement will be finalized. Steam cooling and rotor air cooling functional design will be completed and a design approach selected. Static start vendors will be evaluated. And finally, the Architect-Engineering firm will be selected.

\section{TASK 4.1 STEAM TURBINE}

The thermodynamic cycle was modified resulting in a slight increase in steam flow to the steam turbine. Blade path work continues to support these revised targets. A coordination meeting with manufacturing was held to review the new ATS design concepts and solicit input for methods to reduce manufacturing costs and lead times. Working level meetings with vendors is slated for April.

\section{TASK 8.0 INTEGRATED PROGRAM PLAN}

No activity was generated this quarter.

\section{TASK 9.1 CLOSED LOOP COOLING}

The leakage/durability test at STC was be pushed back a month due to a late delivery date on a superheater. The test at STC is scheduled to begin with the hydrostatic shakedown of the test rig on the 21st of April. A trip to STC is planned for sometime between April 28th and May 2nd, to observe some of the testing.

Purchase orders have been released for the manufacture of the ATS test vessel and the sealing assemblies for the temperature and emissions probes. Valve sizing and selection has been completed. Quotes were received for vane transition blocks, instrumentation, vessel support structure and main support/instrumentation assembly. Schedule challenges however, are substantial due to delays in acquiring the test vane and scheduled shipment date of Aug 30 for the transition.

\section{TASK 9.2 THIN WALL CASTING DEVELOPMENT}

Casting of the first set of thin wall vanes is complete. A review with Allison-SCO will be held in Orlando the week of April 14th to evaluate the casting results. All test vane end cap drawings have been released and the procurement cycle is in progress. The program is 3 weeks behind schedule due to casting issues. Working meetings are planned at Allison-SCO the week of April 21st and topics to be covered include: schedule, weld repair, machining, and the next scheduled metal pour.

\section{TASK 9.3 ROTOR AIR SEALING DEVELOPMENT}

A purchase order was released with John Crane, Inc. for designing, fabrication, and testing a rear face seal for the ATS engine. Commercial terms required further negotiations before closure. All issues appeared to be resolved and the purchase order is being amended. The vendor work is expected to commence in April. Completion of the effort including rig testing is still scheduled for late 1997. 


\section{TASK 9.4 COMPRESSOR AERODYNAMIC DEVELOPMENT}

Advanced Scientific Computing (ASC) began work on modeling the inlet transition. Meetings were held in Orlando with PTA and NAVSSES for the compressor testing. Instrumentation details were discussed with PTA. The agenda with NAVSSES included a manufacturing update, auxiliary equipment status, test facility design, the inlet system, and bleed flows, to name a few. Acoustic instrumentation requirements were better defined. In addition, an intermediate design review was held. A concern about the inlet flow path was expressed, but it has been subsequently addressed.

A meeting was held in Orlando with Power Tech. Associates and Casselberry Lab personnel to discuss instrumentation installation, data acquisition interfaces, and to designate installation responsibilities among the concerned parties. Advanced Scientific Computing continued their CFD analysis of the inlet. In addition, inlet and exhaust information was provided to consultant Peter Brogel of Switzerland to review and assess the design of the test rig. A purchase order for two bleed flow coolers was placed with Unafin and the design has since been approved for fabrication.

Assistance from the production engineering group was sought and received. Several meetings occurred concerning ancillary equipment and support systems (valves and actuators, controls, lube oil, etc.). A rig audit of the schedule was held in Orlando; various alternatives to the present schedule were considered but ultimately rejected. NAVSSES released their final design of the inlet ducting. Consultant Peter Brogle released his report of the inlet system, which contained some useful recommendations.

\section{TASK 9.5 TURBINE AERODYNAMIC DEVELOPMENT}

Approximately half the large turnings(large rings for turbine rig containment) have been delivered to Calspan with the remaining items scheduled delivery next quarter. The Calspan shop has begun fabrication of the first stage components with estimated delivery in May. The remaining components for stage two are scheduled for delivery by mid August.

The instrumentation pockets and wire-ways have been machined into the stage one blades and vanes. The final cleaning and prep of the airfoils has been completed with the appropriate airfoils being forwarded to Kulite for instrumentation installation. The second stage vanes are being machined for instrumentation while the second blades are being laid-out for machining at a second vendor.

The Pyrex buttons for the heat-flux gauges were delivered to OSU on 1/31 and hand carried to the vendor in New York who is painting the thin-film platinum gauges. Complete gauges should be ready for installation by early April. The entire stage one instrumentation is scheduled for completion by early June. The construction of the test building shell was completed. Assembly of test facility internals is ongoing at OSU. Blade locking plates were ordered and should be completed by the end of April. Disk one is scheduled for delivery on April 24 and disk two on April 30. 
The stage one experimental measurements are currently scheduled to begin in late July. This schedule is driven by two major tasks. The first being the facility erection and performance of the $P \& W$ experiment. The second being the instrumentation of the stage one ATS turbine, as discussed above. With regards to the facility erection, the building is now complete. The TTF must be operational by early April to maintain the current schedule. The $\mathrm{P} \& \mathrm{~W}$ turbine is currently ready to be installed. A preliminary CFD report was received from OSU. Addition of inlet turbulence intensity variation for two stage test is still pending.

Three Vane 2 airfoils will be sent to Winston Salem for geometric checks. Vane 2 assembly was completed and shipped to OSU.

OSU is looking into using Unsflo for unsteady aero analysis. Westinghouse CT engineering will evaluate the generic CFD codes Rampant and Star-Cd for unsteady aero and heat transfer analysis.

\section{TASK 9.6 ADVANCED AIR SEALING DEVELOPMENT}

A task review was held at the brush seal vendor, EG\&G. Planned sub-tasks and the schedule were reviewed. The re-start of aero performance rig testing had been delayed until early April because of rig adjustments necessary to accommodate the new tapered rotor system. The first brush seal to be rig tested is a generic one for the turbine interstage location to validate operation of the modified rig. Full-scale compressor diaphragm brush seal manufacturing continued in March with a trial seal segment successfully welded. The delivery. schedule of full-scale seals was coordinated with the ATS compressor rig assembly so the brush seal will be able to be installed before shipment of the compressor for testing.

\section{TASK 9.7 ACTIVE TIP CLEARANCE CONTROL}

This task involves developing abradable coatings for both the compressor and turbine outer air seals which are opposite of the rotating blade tips. In March, Sermatech International was issued a purchase order to evaluate the abradability and erosion characteristics of two types of compressor abradable coatings. Test samples have been coated and rig testing is schedule to start in May. Praxair was issued a purchase order to evaluate blade tip treatments for the ATS first turbine stage. Such treatments are to provide thermal insulation for the blade tips and wear resistance when rubbing against ceramic abradable coated ring segments. P\&W Talon is expected to also submit a proposal for blade tip treatments in late-April or early May.

\section{TASK 9.8 COMBUSTION SYSTEM DEVELOPMENT}

Manufacturing work continues on the ATS prototype combustor. In lieu of the actual test combustor, we ran atmospheric fired tests on a similar Piloted Ring combustor configuration with very good results. Low single digit $\mathrm{NOx}$, as well as single digit $\mathrm{CO}$, and $\mathrm{UHC}$ together with low pressure fluctuations were observed in the tests. Variations in primary stage swirl 
configuration (co-swirl and counter swirl) were tested while the combustion process itself was observed using a video camera mounted inside the test rig.

\section{TASK 9.9 CERAMIC RING SEGMENT}

As the result of earlier reported deficiencies in the substrate Nicalon Alumina, no other work will be done on this material system and the ceramics development program will be discontinued under the ATS program in 1997.

\section{TASK 9.10 ADVANCED THERMAL BARRIER COATING DEVELOPMENT}

Testing of bond coats has exceeded 15,800 hours at the nominal test temperature. Additional bond coats were placed into the fumace in March. New ceramics, are being tested both as free standing materials and as TBC top coats. Two new EB-PVD TBC's were successfully deposited onto ceramic substrates. Evaluation of the new ceramics is ongoing. Evaluation of hardware from deposition trials is continuing; the findings to date have been encouraging.

\section{TASK 9.11 STEAM COOLING EFFECTS}

Test run \#1 was conducted at Southwest Research Institute (SwRI) during February which resulted in the plugging of all but one of the 12 specimens in a matter of 2 to 3 days. The contaminant levels chosen for the first test were extremely high, and a short test was expected. Destructive analysis of some of the specimens has been conducted to determine the extent of the attack from the contaminants. The analysis showed that in addition to the expected compounds of the intentionally added contaminants in the steam, other elements such as $\mathrm{Ca}, \mathrm{Mg}$ and excess $\mathrm{Si}$ were present. The sources of these unplanned contaminants will be investigated and removed before running the next test. Hot corrosion on specimens was identified.

Preparations for the second test were initiated. Normal steam chemistry will be run. Specimen plugging is estimated to occur in six weeks.

\section{TASK 9.12 DIRECTIONALLY SOLIDIFIED BLADE DEVELOPMENT}

Tensile, fatigue and short term creep tests of CC CM247LC were completed. Long term tests of CC CM247LC are in progress. Creep and fatigue tests of CM247LC and MM002 DS materials (with 3,6, and 12"/hour withdrawal rate) are in progress. Effects of coating on creep and fatigue properties are being evaluated for DS MM002 material. CC and DS blades of CM247 and MMO02 materials are being machined and evaluated for tensile, creep and fatigue properties. 


\section{TASK 9.13 SINGLE CRYSTAL BLADE DEVELOPMENT PROGRAM}

A meeting was held at Howmet (Hampton) to discuss casting of the ATS R2 blade. At this meeting freckle control, core design and modeling were discussed in depth. Howmet (Hampton) is currently suffering from a manpower shortage so future casting trails will be performed at Howmet (Whitehall). A statement of work has been submitted to Whitehall, and a quote should be available for mid-April. A kick-off meeting with Whitehall is planned for mid April.

Thick wall CMSX-4 test coupons were selected and shipped to two testing vendors for final specimen machining and testing. Tensile, LCF, HCF, and creep rupture tests will start in next month. Charpy V-notch impact testing has been completed. Thin wall test specimens have been cast, heat treated and inspected by Allison. These specimens will be delivered to Westinghouse early next month. Isothermal oxidation test pins exposed at $1550 \mathrm{~F}, 1650 \mathrm{~F}$ and $1750 \mathrm{~F}$ for up to $1000 \mathrm{hr}$. have been sectioned for metallographic evaluation, and the results are being analyzed. Long term (over 10,000 hr) creep rupture tests being conducted at Joliet Metallurgical Labs have clocked over $2100 \mathrm{hr}$ of testing time.

\section{TASK 9.14 ADVANCED VANE ALLOY DEVELOPMENT}

High temperature structural bonding of candidate vane materials is being investigated. The majority of test data from preliminary mechanical properties tests have been received from two potential bonding vendors. Complete data from these tests are expected by the middle of April. Selection of the bonding vendor is expected to occur in April, so that further concurrent design of the vanes can be pursued.

\section{TASK 9.15 BLADE AND VANE LIFE PREDICTION}

Substrates for curvature / roughness testing have been sent to CUK for coating. Furnace cycling at $1975 \mathrm{~F}$ of stepped bars (provided by RR) on the way - some premature failures after only 200 hours due to edge effects are notable. Convergence problems of Walker code were discussed with $T$. Cruse - basically the number of time steps needs to be adjusted individually. Next a generic cycle provided by P. Garbett will be run.

Testing was performed on tension/compression specimens coated with TBCs. Micrographs of stepped bar samples were analyzed for TGO and bond coat thickness. In April LCF testing will continue. In addition, curvature and surface roughness samples will be tested.

\section{TASK 9.16 NICKEL BASED ALLOY ROTOR}

Fracture toughness testing of IN706 disc material from ALCOA was completed. Long term stress rupture testing of this material at lower stress levels continues to show non - notch sensitive behavior. Initial stress rupture results from the Westinghouse IN706 test disc from Wyman Gordon (two step heat treated) have confirmed the notch sensitive behavior exhibited by the ALCOA material. A three step heat treatment on IN706 material was performed at Wyman 
Gordon to attempt to reduce its notch sensitivity in creep. Machining of test specimens will begin next month.

\section{TASK 9.17 TRANSITION MOUTH SEALING AND COOLING DEVELOPMENT}

A purchase order was placed with EG\&G Sealol to fabricate prototype welded bellows transition mouth seals. A review was held at EG\&G to agree upon final design details, establish a schedule, and initiate work. Bellows seals are to be delivered in July for evaluation in the ATS combustor rig test. Stein Seal has been contacted about alternative sealing approaches.

\section{TASK 9.18 ROTOR COOLING AIR COMPRESSION/DIFFUSER DEVELOPMENT}

Concepts ETI continued their contracted effort of evaluating the rotor cooling air system design and planning of a subscale rig test. They are focusing on compression of the rotor cooling air as it flows between rotor disk cavities and diffusion as it flows through exit deswirlers. In April, Concepts will meet at Westinghouse to review their task phase 1 results and discuss testing to be proposed for a second phase.

\section{TASK 11.0 PROGRAM MANAGEMENT}

The required Federal Assistance Reports were developed and submitted during each month of the quarter. A quarterly review meeting was held on February 13 \& 14, 1996 in Morgantown. 


\section{CONCLUSION}

Activities on all tasks proceed according to plan, with minor delays in seal development, steam cooling effects tasks and single crystal blade development. The required Federal Assistance Reports were written and submitted on time. Planned activities for the next quarter are explained below.

\section{Tasks}

1.0 NEPA Information

No activity.

\subsection{ATS Engine Design}

Continue ATS engine component design.

4.0 Steam Turbine

Continue with design work.

8.0 Integrated Program Plan

Update the integrated program plan to incorporate new tasks.

9.1 Closed Loop Cooling

Continue shakedown of hot cascade/combustion test rig.

9.2 Thin Wall Airfoil Casting Development

Evaluate first casting results.

Ship first test vane.

9.3 Rotor Sealing Development

Continue rear face seal rig testing.

Document rear seal assembly procedures.

9.4 Compressor Aerodynamic Development

Continue design of ancillary equipment.

Continue manufacture of compressor/combustor cylinder.

9.5 Turbine Aerodynamic Development

Continue work at Ohio State University on model turbine test rig.

Complete machining of blade/vane instrumentation.

9.6 Advanced Air Sealing Development

Continue model brush seal rig tests.

Continue manufacture of full scale brush seals. 
9.7 Active Tip Clearance Control System Development

Evaluate P\&W blade tip treatment proposal.

Evaluate EG\&G proposal to test thermally insulated tip treatments.

9.8 Combustion System Development

Continue bench scale testing of catalyst section.

Continue scale up activities of active noise control system.

9.9 Ceramic Ring Segments

No activity

9.10 Advanced TBC Development

Bond coat materials currently in test will be continued.

Additional bond coat chemistries are being formulated and will be deposited and brought to test.

New ceramic TBC powders which have been fabricated will be deposited and brought to test.

Additional ceramic compositions have been defined; powders and subsequently coating specimens, will be fabricated.

9.11 Steam Cooling Effects

Continue testing.

\subsection{DS Blade Development}

Continue specimen creep testing for continuous cast blade evaluation.

Continue DS blade specimen low cycle fatigue and creep testing.

Continue HCF \& creep testing of DS CM247 blades.

Evaluate DS M002 blades.

9.13 SC Blade Development

Continue test single crystal CMSX-4 cast slabs, heat treat and machine test specimens.

Continue preliminary SC blade design and cost-and-benefit analysis.

Complete analysis of isothermal oxidation test pins.

9.14 Advanced Vane Alloy Development

Continue baseline testing of alloy IN-939.

Computer modeling of alloy composition will continue.

Casting and testing of small heats of experimental alloys for weldability and mechanical properties will continue at Oak Ridge National Laboratory.

Select bond coat vendor 
9.15 Blade and Vane Life Prediction Continue refinement of life prediction model for a TBC system.

Critical material behavior will be defined and a plan for conducting tests to measure these properties will continue to be developed.

Testing to determine critical properties of bond coat and ceramic top coat will continue.

\subsection{Ni-Based Superalloy Rotor}

Continue testing of turbine disks.

Issue purchase order for IN706 heat treatment.

\subsection{Transition Mouth Sealing and Cooling Development}

Accept delivery of bellows seals.

Investigate alternative sealing methods with Stein Seal.

9.18 Rotor Cooling Air Compression/Diffuser Development

Continue design of subscale test rig.

Discuss testing in phase 2 of Concepts ETI work

11.0 Program Management "

Submit monthly reports.

Plan and prepare for seventh quarterly review in June 1997.

Finalize quarterly report TPR-07

Mark Krush

Program Manager 


\section{LIST OF ACRONYMS AND ABBREVIATIONS}

\begin{tabular}{|c|c|c|}
\hline $\mathrm{A} / \mathrm{E}$ & & Architect/Engineer \\
\hline AEDC & & Arnold Engineering Development Center \\
\hline ASPEN & • & Process Simulator Software \\
\hline ATCC & & Advanced Technology Catalytic Combustor \\
\hline ATM & & Atmospheres \\
\hline ATS & & Advanced Turbine Systems \\
\hline BOP & & Balance-of-Plant \\
\hline $\mathrm{CC}$ & & Conventionally Cast \\
\hline CDA & & Controlled Diffusion Airfoils \\
\hline CFATS & & Coal/Biomass-Fired Advanced Turbine Systems \\
\hline CFD & & Computational Fluid Dynamics \\
\hline CLSC & & Closed-Loop Steam Cooling \\
\hline CM247 & & Ni-Based Blade Alloy \\
\hline CMC & & Ceramic Matrix Composite \\
\hline CMSX-4 & & Single Crystal Alloy (By Cannon-Muskegon) \\
\hline $\mathrm{CO}$ & & Carbon Monoxide \\
\hline $\mathrm{CO} 2$ & & Carbon Dioxide \\
\hline COR & & Contracting Officer's Representative \\
\hline CT & & Combustion Turbine \\
\hline CUK & & Chromolloy United Kingdom \\
\hline DBFR & & Design Basis/Functional Requirements \\
\hline DLC & - & DuPont Lanxide Composites \\
\hline DOE & & Department of Energy \\
\hline DS & & Directionally Solidified \\
\hline EB-PVD & & Electron Beam Physical Vapor Deposition \\
\hline ECY -768 & & Cobalt-based Alloy \\
\hline EGR & & Exhaust Gas Recirculation \\
\hline EIS & & Environmental Impact Statement \\
\hline FE & & Finite Element \\
\hline FETC & & Fossil Energy Technology Center \\
\hline FLR & $\cdot$ & Focused Light Rig \\
\hline FMEA & & Failure Modes and Effects Analysis \\
\hline GATE & & Power Cycle Simulator Software \\
\hline GFATS & & Gas-Fired Advanced Turbine Systems \\
\hline $\mathrm{HCF}$ & & High Cycle Fatigue \\
\hline $\mathrm{HP}$ & & High Pressure \\
\hline HRSG & & Heat Recovery Steam Generator \\
\hline HVAC & & Heating, Ventilation, Air Conditioning \\
\hline ICP & & Integrated Catalytic Pilot \\
\hline IN-738 & $\cdot$ & Ni-based Alloy \\
\hline IN-939 & & Ni-based Alloy \\
\hline IP & & Intermediate Pressure \\
\hline KRW & & Kellogg-Rust-Westinghouse \\
\hline
\end{tabular}




\section{LIST OF ACRONYMS AND ABBREVIATIONS}

\begin{tabular}{ll} 
LCF & Low Cycle Fatigue \\
LHV & Lower Heating Value \\
LP & Low Pressure \\
MCSSB & Multiple Catalytic Swirl Stabilized Burner \\
MMI & Man Machine Interface \\
NDE & Non-Destructive Examination \\
NEPA & National Environment Policy Act \\
NES & National Energy Strategy \\
NOx & Nitrous Oxides \\
ORNL & Oak Ridge National Laboratory \\
O2 & Oxygen \\
P\&ID & Piping and Instrumentation Diagrams \\
PCD & Process Controls Division \\
PFBC & Pressurized Fluidized Bed Combustion \\
RAM & Reliability, Availability, Maintainability \\
RD\&T & Research, Design and Test \\
SC & Single Crystal \\
SCAP & Solicitation for Cooperative Agreement Proposal \\
ST & Steam Turbine \\
TBC & Thermal Barrier Coatings \\
TBC & Thermal Barrier Coatings \\
TGO & Thermally Grown Oxide \\
TMF & Thermal, Mechanical Fatigue \\
UHC & Unburned Hydrocarbons \\
ULN & Ultra-Low NOx \\
WBS & Work Breakdown Structure \\
WDPF & Westinghouse Distributed Processing Family \\
& \\
\hline
\end{tabular}


Report Number (14)_DOE/MC/32267- $/ 5782$

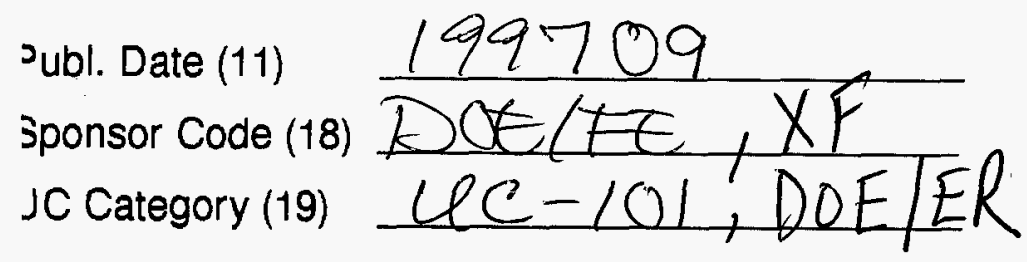

